\section{Why I am interested in acute care surgery as my career}

\author{
Toba Bolaji
}

For as long as I can remember, in my pursuit of medicine and surgery, I have always been intrigued by the field of trauma. Truthfully, my interest was based in a fantasy of what I thought the field represented and who I thought trauma surgeons were. For me, it meant being a real-life superhero, using your mind and hands to save lives. I assumed the archetype of all trauma surgeons was the person waiting for the next challenge, with nerves of steel and the ability to command a room by their presence. My infatuation was more about the perception of the work, the highs, and the glory.

Surgery is audacious. It's an audacity that is pronounced in trauma surgery. It's a confidence in our training, our knowledge base, practiced maneuvers and skills that says we will save your life. But once you've done the work, and you realize that traumatic injuries can often be unforgiving, there lives a humility in every trauma surgeon that acknowledges that we cannot do it all.

One Saturday morning, while on-call, a page was sent through our hospital overhead system of an incoming trauma code activation 10 mins from the hospital. The trauma surgery team assembled, and hastily made our way down to the trauma bays. There, we received our briefing:

Young African- American male, status post gunshot wound to the right chest. Hypotensive, tachycardic and agonal in the field

With that briefing we knew that his injuries were likely severe. We gathered central lines, betadine cleansing solution and chest tube kits on either side of the room. My chief instructed that I bring out the thoracotomy tray, assume the left chest position, and if the patient entered our bay in cardiac arrest, I should perform an resuscitative thoracotomy.

Surgery, Christiana Care Health System, Wilmington, Delaware, USA

Correspondence to Dr Toba Bolaji; tobabolaji@gmail. com realized that trauma surgeons can't do it all. We are often limited by the boundaries of time, resources, and physiology. But one of the opportunities I have found in this career and specifically in this specialty is an opportunity to care for these patients in a way that extends our inpatient efforts. Through hospital violence injury prevention (HVIP) programs, student mentorship and exposure, as well as national programs like Stop the Bleed, the field of trauma has started to recognize the limitations of medicine and surgery and considers the socioeconomic determinants of health on this community.

I want a career in acute care/trauma surgery because more than the surgery itself, I've found a specific purpose to my community-one of representation and hope, as well as wellness and advocacy. Through my experiences in mentorship, I show that being a physician is possible, practical and the hard work and delayed gratification is worth it. Through my work with HVIP, we know that perpetrators of gun violence are often former victims and providing equitable access to follow-up care disrupts that cycle. Lastly, through national programs like Stop the Bleed and explicit efforts on gun control reform, I've found a way to empower and advocate for minority and under-represented communities in ways that go beyond the hospital walls.

Truthfully, I still think that trauma surgeons are real-life superheroes, but the reasons why are far beyond their demeanor and the surgery. I have become equally passionate about providing care for my patients through programs and efforts that see people and communities as those who deserve equitable care and committed advocacy. I've always been thankful for the privilege of being chosen to do the work I do, and I'm excited for a long career that bears that fruit. than I would have thought within a short encounter.

That young man reminded me of myself and so many of the young men I grew up with. Men whose lives were cut short by gun violence. Since this incident, we've lost many more young men, victims of gun violence, who are brought to the emergency department in extremis, who we unfortunately cannot save. Yes, as surgeons, we strive to be better at our craft. We strive to know more. Many of us learn new skills and approaches deep into our career for the purposes of being able to offer our patients better care. But many times, especially in trauma, our efforts are delayed, we aren't good enough and people die. In my short career, I've already
Funding The authors have not declared a specific grant for this research from any funding agency in the public, commercial or not-for-profit sectors.

Competing interests None declared.

Patient consent for publication Not applicable.

Provenance and peer review Commissioned; internally peer reviewed.

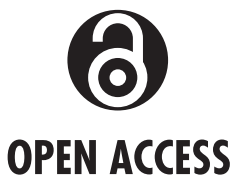

Open access This is an open access article distributed in accordance with the Creative Commons Attribution Non Commercial (CC BY-NC 4.0) license, which permits others to distribute, remix, adapt, build upon this work non-commercially, and license their derivative works on 
different terms, provided the original work is properly cited, appropriate credit is given, any changes made indicated, and the use is non-commercial. See: http:// creativecommons.org/licenses/by-nc/4.0/.

(c) Author(s) (or their employer(s)) 2021. Re-use permitted under CC BY-NC. No commercial re-use. See rights and permissions. Published by BMJ.

\section{A Check for updates}

To cite Bolaji T. Trauma Surg Acute Care Open 2021;6:e000864. doi:10.1136/tsaco-2021-000864

Received 16 November 2021

Accepted 18 November 2021

\section{Linked}

- http://dx.doi.org/10.1136/tsaco-2021-000853

- http://dx.doi.org/10.1136/tsaco-2021-000867

Trauma Surg Acute Care Open 2021:6:e000864. doi:10.1136/tsaco-2021-000864 